\title{
Keeping Quality of Wheat-Groundnut Protein Concentrate Flour
}

\author{
Zubair AB*, Maxwell YMO, Femi FA, Teidi RO, Ocheme OB \\ Department of Food Science and Technology, Federal University of Technology, Nigeria
}

\begin{abstract}
Keeping the quality of wheat-groundnut protein concentrate flour was investigated. Groundnut was processed into groundnut protein-concentrate (GPC) and blended with wheat flour (WF) at ratios 100:0, 95:5, 90:10, 85:15 and 80:20 (WF:GPC). The blends were packaged in high-density polyethylene bags and were stored at ambient conditions for eight weeks during which the proximate composition and functional properties were determined using standard methods. There was a significant decrease in protein (30.58-18.71) and fat content (10.00-6.00) during storage while the crude fiber significantly increased (0.99-0.89). The ash content (1.50-1.51) and moisture content (6.75-7.75) show no significant difference throughout the period of storage. The bulk density showed a significant decrease (0.61-0.52) during storage. Water and oil absorption capacity showed no significant difference (1.30-1.20). Storage period has a significant effect on most of the analyzed parameter.
\end{abstract}

Keywords: Wheat; Bulk density; Crude fibre; Groundnut protein; Flour

\section{INTRODUCTION}

Wheat is the major cereal crop of the world and it is consumed mainly in the form of bakery products such as bread, cakes, and biscuits [1]. The suitability of wheat for the preparation of these products is due to its gluten content which is responsible for the formation of viscoelastic dough when hydrated with water [1]. Wheat contains complex carbohydrate, dietary fiber, a moderate amount of protein, rich in minerals (such as magnesium, calcium, and potassium), vitamin-B, vitamin-E and abundant in antioxidants mostly carotenoids like beta-carotene [2]. Wheat has been found to be limited in tryptophan and lysine, these necessitated interest in research on flour from locally available crops to produce composite flour to improve on the nutritional quality of wheat flour-based product as well as reduce the high cost associated with the importation of wheat [3-5]. The demand for bakery products such as bread is increasing due to the fact that they are ready-to-eat food items with good nutritive value, low in fat and mostly used as breakfast all over the world [3].

Groundnut is one of the most important low price cash crop, rich in essential nutrients like protein, minerals, and antioxidants [6]. Incorporating groundnut protein concentrate on wheat-based products helps in balancing some essential nutrients [7]. The objective of this study is to increase the protein content of the wheat flour both in quality and quantity through the inclusion of groundnut protein concentrate due to the fact that they lack some essential amino acid like tryptophan and lysine and our objective was to observe its storage stability.

\section{MATERIALS AND METHODS}

\section{Materials}

Groundnuts (Arachis hypogeal) and wheat flour (Honeywell) were obtained from Kure Central Market, Minna, Niger State.

\section{Methods}

Preparation of groundnut protein concentrate: Defatted groundnut flour was produced using the procedure described by Yu et al. [8] with slight modification. The groundnut seeds were cleaned, sorted and roasted at $100^{\circ} \mathrm{C}$ for $10 \mathrm{~min}$ and allowed to cool after which it was de-coated by rubbing between hands and blended using a master chef high-speed blender to obtain a paste. About $500 \mathrm{~g}$ of the groundnut paste was defatted using solvent extraction method. The groundnut paste was wrapped with filter paper and put inside a solvent extractor. The $\mathrm{N}$. hexane was filled into a fat-free round bottom flask up to $2 / 3$ of the volume of the flask; the soxhlet apparatus was assembled and

Correspondence to: Zubair AB, Department of Food Science and Technology, Federal University of Technology, P.M.B. 65, Minna, Niger State, Nigeria, Tel: +2348035889779; E-mail: b.zubair@futminna.edu.ng

Received: June 03, 2019; Accepted: July 15, 2019; Published: July 25, 2019

Citation: Zubair AB, Maxwell YMO, Femi FA, Teidi RO, Ocheme OB (2019) Keeping Quality of Wheat-Groundnut Protein Concentrate Flour. J Food Process Technol 10:808. doi: 10.35248/2157-7110.19.10.808

Copyright: ( $) 2019$ Zubair AB, et al. This is an open-access article distributed under the terms of the Creative Commons Attribution License, which permits unrestricted use, distribution, and reproduction in any medium, provided the original author and source are credited. 
allowed to reflux for $6 \mathrm{~h}$ with a heating mantle (KDM 1000) adjusted to $(70-800)^{\circ} \mathrm{C}$. The filter paper was removed from the solvent extractor and air-dried for $48 \mathrm{~h}$ to remove solvent odor. The dried groundnut flour was mixed with distilled water in the ratio of $1: 10(\mathrm{w} / \mathrm{v})$ and the $\mathrm{pH}$ of the mixture adjusted to 4.0-8.0 with $1.0 \mathrm{~N}$ sodium hydroxide $(\mathrm{NaOH})$ and HCL. The suspension was centrifuged at $3500 \mathrm{rpm}$ for $30 \mathrm{~min}$. The supernatant was discarded and the precipitate was re-suspended in the water at ratio $1 / 10(\mathrm{w} / \mathrm{v})$ and stirred at room temperature for $1 \mathrm{~h}$. The suspension was centrifuged again at $3500 \mathrm{rpm}$ for $30 \mathrm{~min}$. The supernatant was discarded and the precipitate was removed from the tube, dried in an oven at $40^{\circ} \mathrm{C}$, packaged and stored for further use.

Formulation of blends of wheat flour and groundnut protein concentrate: Wheat flour and groundnut protein concentrate were blended $(0 / 0 \mathrm{w} / \mathrm{w})$ at the ratio $100: 0,95: 5,90: 10,85: 15$ and $80: 20$, with $100 \%$ wheat flour serving as a control sample. All the samples were homogenized for uniformity.

Sample analyses: Moisture, ash, protein, fat, fibre, carbohydrate, and peroxide values were determined using a standard method [9]. Bulk density of the samples, water, and oil absorption capacity were determined using the method outlined by Onwuka [10]. Gelation capacity was determined using the method described by Coffman and Garcia [11]. Foaming capacity was determined using the method described by Lawhon et al. [12]. Emulsifying capacity was determined using the method described by Adebowale et al. [13].

All experiments were carried out in triplicate. Data obtained were subjected to one-way analysis of variance while Duncan's multiple range test was conducted to separate the means. These were done using the Statistical Package for the Social Scientists (SPSS version 16.0).

\section{RESULTS AND DISCUSSION}

\section{Proximate composition of a blend of GPC and wheat flour}

The proximate composition of blends of ground protein concentrate and wheat flour during storage is shown in Figures 1-6. Observation of the results from week two to week eight shows a significant and progressive decrease in crude protein and crude fat, while crude fibre increased. The decrease in protein (30.58-18.71)\% could be attributed to the rate of proteolytic activities during storage occasioned by increased moisture content $(6.75-7.75) \%$ [14]. The decrease in fat content (10.00-6.00)\% during storage could be attributed to the lipolytic activities of the enzyme lipase and lipoxidase [14]. The Ash content shows no significant difference (1.50-1.50\%). Ash gives a quantitative estimation of minerals available in a given food product, thus serves as a viable tool for nutritional evaluation [15] (Figures 1-3).

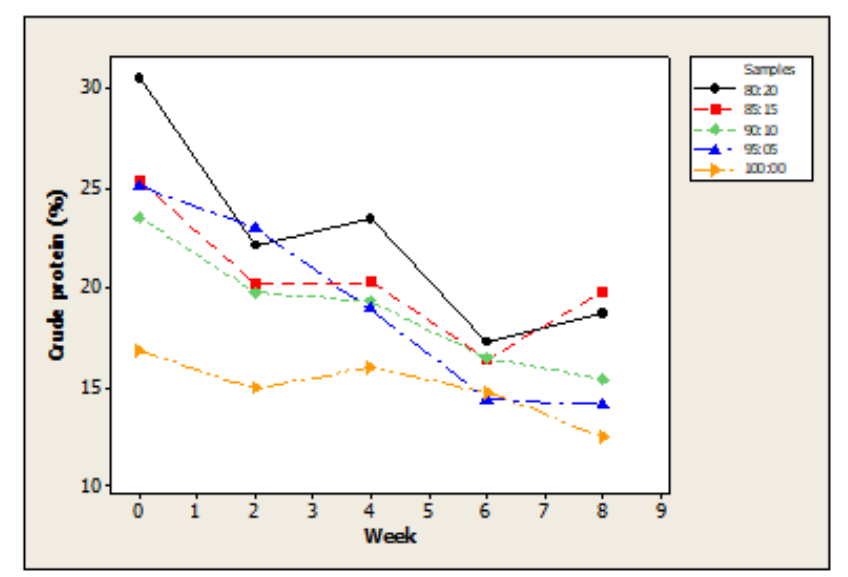

Figure 1: The crude protein content of wheat-GPC flour sample during storage.

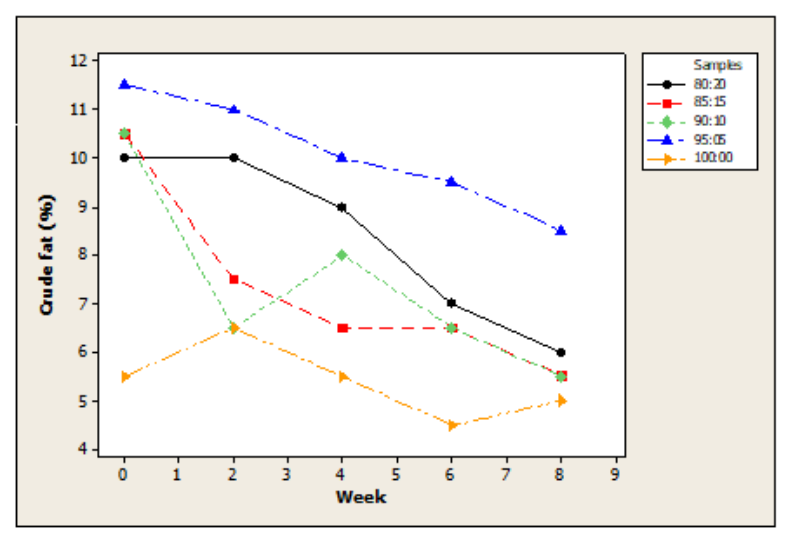

Figure 2: Fat content of wheat-GPC flour sample during storage.

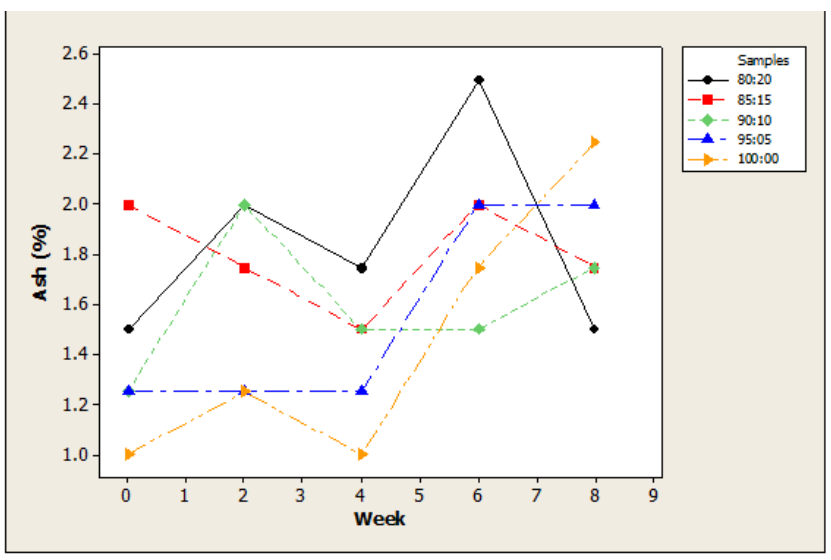

Figure 3: Ash content of wheat-GPC flour sample during storage.

Moisture content (6.75-7.75\%) show a significant difference throughout the storage period (Figure 4). The moisture content was fluctuating and this could be as a result of microbial activities inside the packaging material that catalyzed the release of organic acid as reported on cassava flake [16]. The packaging materials used also has a low water vapor transmission rate as well as higher microbiological activities [14]. There was a significant difference in carbohydrate content (49.46-65.15\%) with sample (80:20) having the lowest carbohydrate level, followed by sample $(85: 15,90: 10,95: 5)$ and (100:0) (Figure 5). 
This could be due to the groundnut protein concentrate inclusion level and decrease in other parameters. The peroxide values are shown in Figure 6. There were significant differences at $(p \leq 0.05)$. Low peroxide value indicates that the oil cannot undergo oxidative deterioration on keeping for a longer period [17].

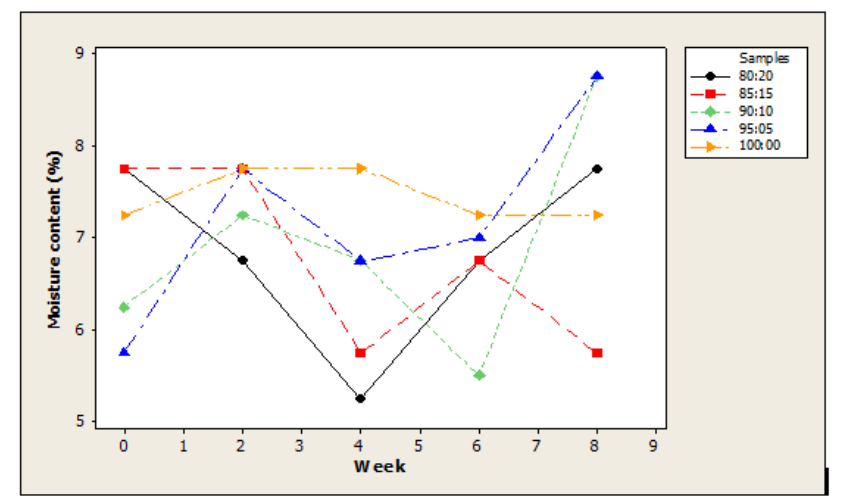

Figure 4: The moisture content of wheat-GPC flour sample during storage.

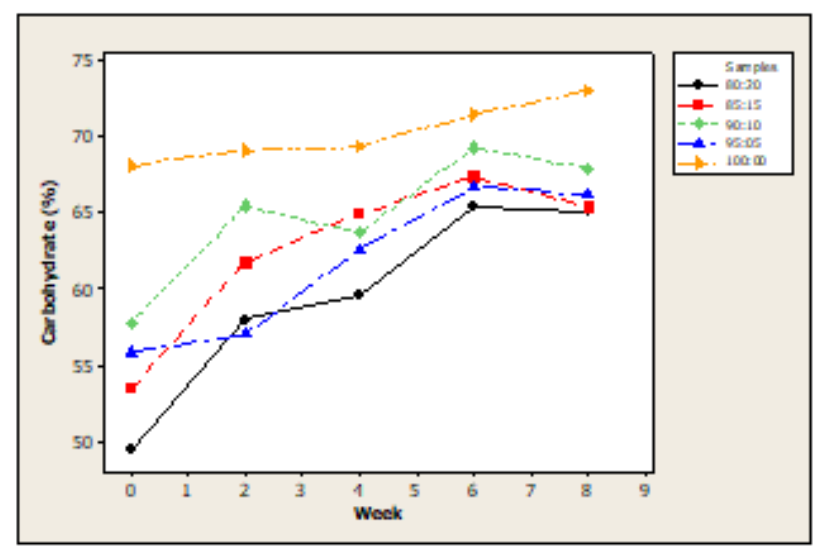

Figure 5: Carbohydrate content of wheat-GPC flour sample during storage.

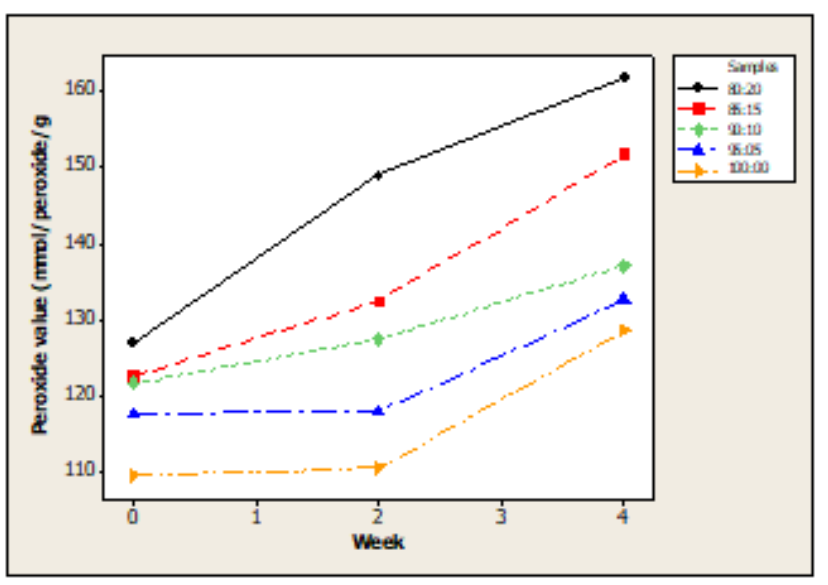

Figure 6: Peroxide value of wheat-GPC flour sample during storage.

Peroxide value shows a positive correlation with increasing storage period. Increase in peroxide value could be attributed to oxidative deterioration.

\section{Effect of storage on the functional properties of the blend}

Functional properties of a food material describe how the food behave during preparation, cooking and how they affect the finished product in terms of how it looks, taste and feel. Thus, food that has good functional properties will make an easy blend with other foods and produce good quality end products. Bulk density show significant decrease during storage from week one to week eight. Bulk density is an indication of porosity of a product which influences packaging design and could be used to determine the type of packaging material required. Low bulk density is important and desirable for infant's foods [18]. Consumption of food item with low bulk density is nutritional of importance because it encourages consumption of more quantities of the lighter food item and thus, translate to more nutrients for the consumer. Water absorption capacity is important in consistency and bulking of products as well as baking characteristics $[19,20]$ shown in Figures 7-11.

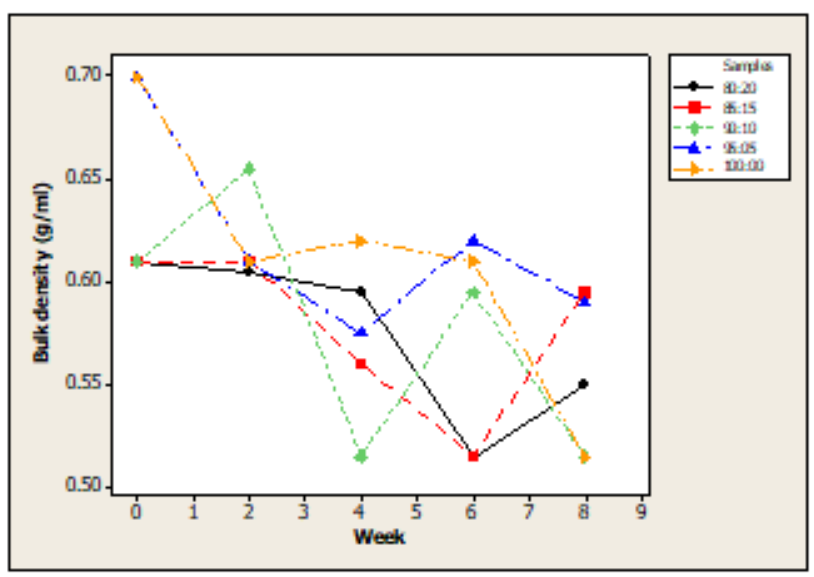

Figure 7: Bulk density of wheat-GPC flour sample during storage.

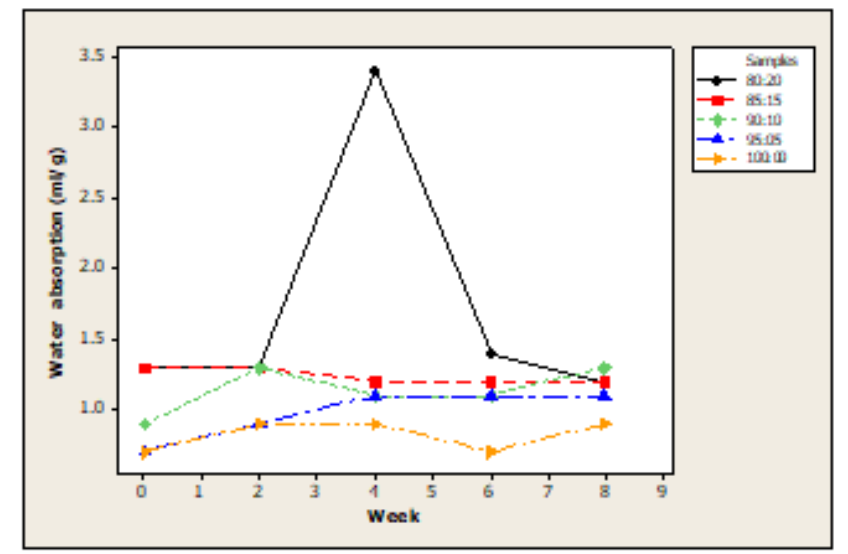

Figure 8: Water absorption of wheat-GPC flour sample during storage difference.

Oil absorption shows a significant increase during storage from week one to week eight from $\left(0.30-2.20 \mathrm{~g} / \mathrm{cm}^{3}\right)$. This could be as a result of the reduction in fat content occasioned by the activities of lipolytic enzymes lipase and lipoxidase [14]. Fat acts as flavor retainer and increases the palatability of foods. Oil absorption is an important property in food formulation. 


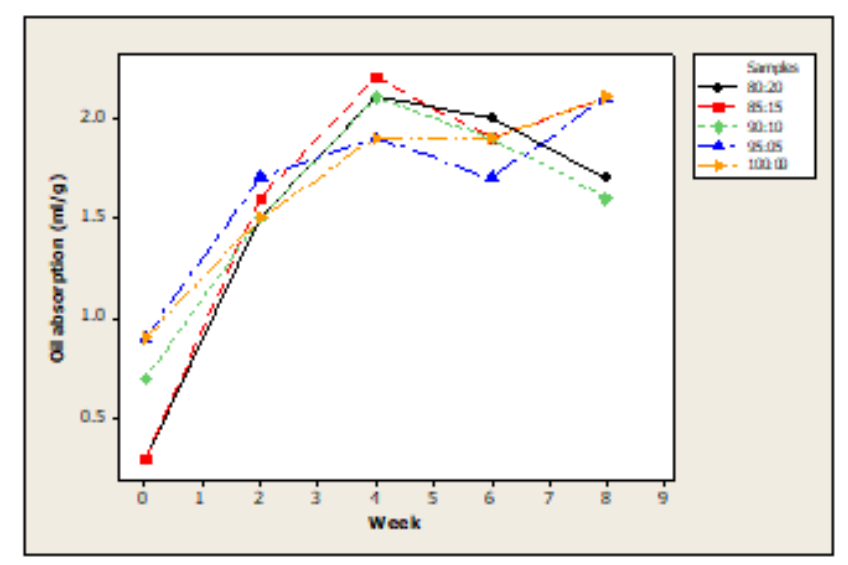

Figure 9: Oil absorption of wheat-GPC flour sample during storage

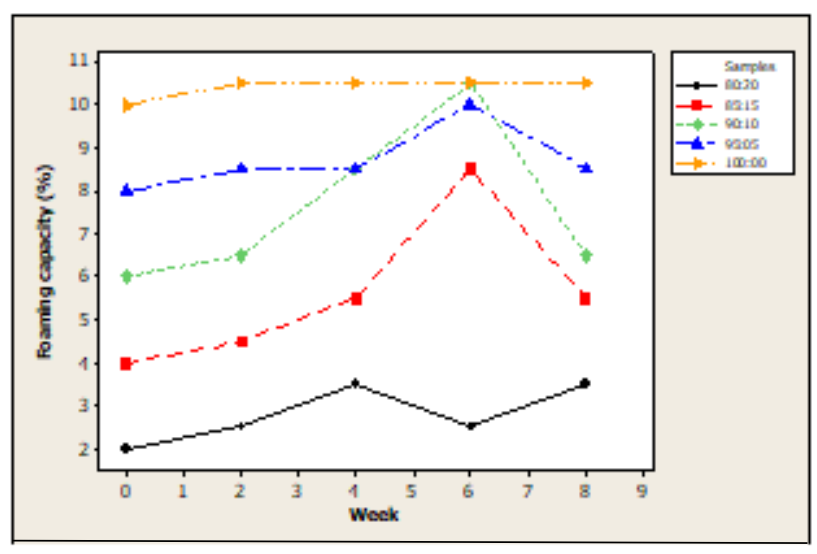

Figure 10: foaming capacity of wheat-GPC flour sample during storage.

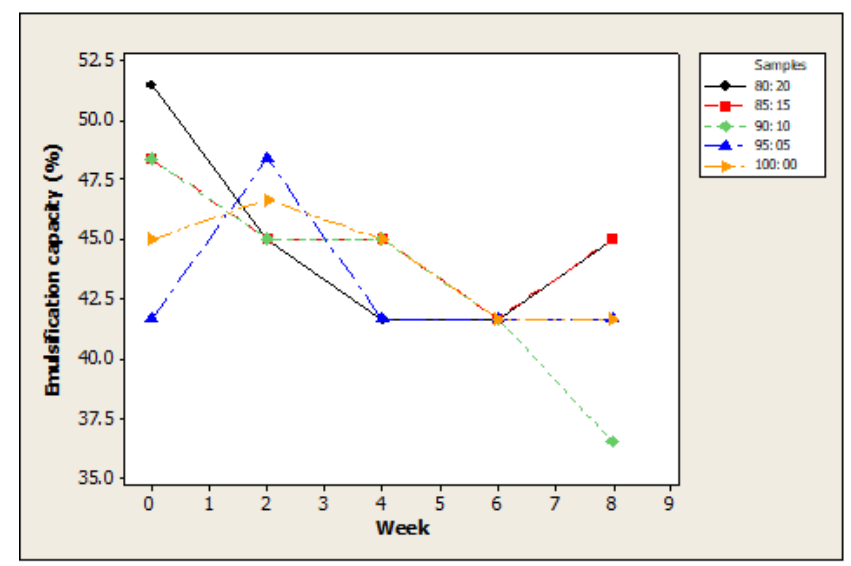

Figure 11: Emulsification capacity of wheat-GPC flour sample during storage.

\section{CONCLUSION}

This study showed the keeping quality of wheat-groundnut protein concentrate flour. Changes occurred during the storage period, the protein content, crude fat, oil absorption capacity, bulk density, and emulsification capacity decreases with increasing storage time, crude fibre, and peroxide increases during storage while other parameters experience slight changes. Protein concentrate flour increases the crude protein level of the wheat flour but reduces with longer storage time. Generally, the flour blends absorb more moisture with increasing storage time which can affect its shelf life. After eight weeks of storage, the flour blends show a good functional property especially lower bulk density which aids easy transportation of product and consumption of more quantity of lighter food and thus translating to more nutrient for the consumer.

\section{REFERENCES}

1. Day L, Augustine MA, Batey IL,Wrigley CW. Wheat gluten uses and Industry needs. Trends Food Sci Technol. 2005;17:82-90.

2. Igbabul BD, Idikwu HO, Inyang CU. Effect of fermentation on some functional properties of Mucuna sloanei and Detarium microcarpum. J Food Technol. 2012;10:83-86.

3. Gupta RB, Masci S, Lafiandra D, Bariana HS, MacRitchie F. Accumulation of protein subunits and their polymers in developing grains of hexaploid wheat. J Experi Botany. 1996;47:1377-1385.

4. Chinma CE, Igbabul BD, Omotayo OO. Quality characteristics of cookie prepared from unripe plantain and defatted sesame flour blends. J Food Technol. 2012; 7:398-408.

5. Adeleke RO, Odedeji JO. Functional properties of wheat and sweet potato flour blends. Pak J Nutr. 2010;9:535-538.

6. Kain RJ, Chen Z, Sonda TS, Abu-Kpawoh JC. Study on the effects of enzymatic hydrolysis on the physical, functional and chemical properties of peanut protein isolates extracted from defatted heat pressed peanut meal flour. Pak J Nutr. 2009;8:818-825.

7. Achu MB, Fokou E, Tchengang C, Fotso M, Tchouanguep FM. Nutritive value of some cucurbitaceae oil seed from different region in Cameroon. Afr J Biotechnol. 2005;4:1329-1334.

8. Yu J, Ahmedna M, Goktepe I. Peanut protein concentration: Production and functional properties as affected by processing. Food Chem. 2007;103:121-129.

9. AOAC. Official methods of analysis 18th ed., Association of official Analytical Chemist, Washington, DC, USA. 2005.

10. Onwuka GI. Food analysis and instrumentation (theory and practice). 1st Ed. Napthali Prints, Surulere, Lagos, Nigeria. 2005:140-160.

11. Coffman CW, Garcia VV. Functional properties and amino acid content of protein isolate from mung bean flour. J Food Technol. 1977;12:473-484.

12. Lawhon JK, Rooney L, Caster CM, Mattil KF. A comparative study of the whipping potential of an extract from several oil seeds flour. Cereal Sci. 1972;17:240-246.

13. Adebowale KO, Olu-Owolabi BI, Olawumi EK, Lawal OS. Functional properties of native, physically and chemically modified breadfruit (Artocarpus artillis) starch Industrial Crops Production. 2005;21:343-351.

14. Agrahar MD, Jha K. Influence of storage and packaging conditions on the quality of soy flour from sprouted soybean. J Food Sci Technol. 2011;48:3258.

15. Lienel HH. Ash analysis. In: Introduction in chemical analysis of food. Nielson. 2000; S.(Ed). CBS Publishers, New Delhi, p: 972.

16. Ogiehor I, Ikenebomeh M. The effects of different packaging materials on the shelf stability of garri. Afr J Biotechnol. 2006;5:741-745.

17. Nnamdi EB, Emendu ER. Proximate Analysis, characterisation and utilization of Bambara nut oil. Int J Sci Res. 2014:4.

18. Iwe MO, Onadipe OO. Effect of extruded full-fat soy flour into sweet potato flour on functional properties of the mixture. Sustain Agric Environ. 2001;3:109-117. 
19. Garba U, Kaur S. Review-protein isolates: Production, functional properties and application. Int Res J Chem. 2014;4:22-36.
20. Nibia M, Bakogan FI, Jackson DS, Schlimme, Li BW. Physiochemical properties and starch granular characteristics of flour from various cassava genotypes. J Food Sci. 2001;67:1701-1705. 